\title{
Analisis Bad Measurement RTU Dengan Menggunakan State Estimasi
}

\author{
Muh. Rais \\ Fakultas Teknik dan Informatika \\ Universitas Patria Artha \\ muh.raisazisnawawi@gmail.com
}

\begin{abstract}
Abstrak - Penelitian ini bertujuan menganalisis hasil pengukuran Remote Terminal Unit (RTU), dan Mendeteksi bad measurement pada bus. Penelitian ini dilaksanakan di PT. PLN (Persero) Wilayah SULSEL pada Area Pengatur danPembagi Beban (AP2B). Data yang digunakan sebagai bahan analisis adalah data impedansi saluran, dan data hasil pengukuran RTU yang terdiri dari data bus, tegangan, injeksi MVAR dan data beban system Kelistrikan SULSELTRABAR. Berdasarkan hasil analisis state estimasi, terjadi bad measurement yang terjadi pada bus akan menyebabkan berkurangnya tingkat keandalan sistem. Kesalahan ukur atau bad measurement dapat disebabkan oleh putusnya komunikasi dari GI ke control center atau tidak terkalibrasinya alat ukur yang ada di gardu induk. Sehingga terjadi kesalahan informasi pada control center.
\end{abstract}

Keywords: Sistem Monitoring, Remote Terminal Unit, State Estimasi

\section{PENDAHULUAN}

Sejalan dengan perkembangan teknologi, dimana ketergantungan terhadap tenaga listrik semakin tinggi sedangkan dipihak lain tersedianya sumber daya alam yang semakin menipis, maka penelitian dan pengembangan baru dalam bidang kelistrikan, elektronika, telekomunikasi dan aplikasi komputer dalam sistem kelistrikan sudah semakin banyak dilaksanakan. Perkembangan dan kemajuan dalam bidang kelistrikan dan elektronika, cukup pesat. Salah satu diantaranya adalah dalam bidang pengelolaan sistem tenaga listrik mulai dari pembangkitan, transmisi, distribusi, pelayanan pelanggan hingga monitoring, yang utamanya ditujukan untuk memperoleh pengelolaan sistem yang aman, dengan mutu yang baik, tetapi dengan biaya yang efisien.

Sistem pengaturan tersebut berkembang mulai dari sistem pengaturan konvensional dimana setiap sub sistem seperti gardu induk memerlukan operator, kemudian dengan sistem pengaturan berbasis komputer agar sistem konvensional tersebut dapat dipantau dan diawasi secara terpusat dari jarak jauh, dan yang terakhir adalah sistem pengaturan yang terintegrasi dimana sub sistem tidak memerlukan operator lagi yang berarti fungsi operator di ambil alih sepenuhnya oleh operator control center.

Salah satu fungsi pemantauan adalah untuk menganalisa security suatu sistem tenaga listrik yaitu dengan cara memantau besaran aliran daya dan tegangan-tegangan pada setiap bus. Dengan sederhana besaran-besaran pengukuran tersebut dapat dengan mudah dibandingkan dengan batas kemampuan dari elemen sistem tenaga listrik, dimana hasilnya dapat digunakan untuk mengantisipasi tindakan -tindakan yang perlu dilakukan sebelum gangguan-gangguan berkembang menjadi serius.

Namun dalam sistem pemantauan terdapat masalah terutama mengenai akurasi sistem pengukuran (tranducer), kesalahan-kesalahan pengukuran sering terbaca secara alamiah pada rangkaian-rangkaian pengukuran maupun kesalahankesalahan yang terikut karena masalah komunikasi data.

Kesalahan-kesalahan yang lain yang mungkin timbul adalah hilangnya data-data pengukuran yang disebabkan putusnya hubungan komunikasi antara control center dengan remote terminal unit yang menyebabkan hanya sebagian dari jaringan yang dapat dipantau oleh operator.

\section{TEORI DASAR}

Remote Terminal Unit adalah salah satu dari suatu sistem pengendalian tenaga listrik yang merupakan perangkat eletronik yang dapat diklasifikasikan sebagai perangkat cerdas. Biasanya ditempatkan di gardu-gardu induk maupun pusat pembangkit sebagai peralatan yang diperlukan oleh control center untuk mengakuisisi data-data rangkaian proses, untuk melakukan remote control, teleindikasi dan telemetering [1].

Pada prinsipnya $R T U$ mempunyai fungsi-fungsi dasar sebagai berikut:

1. Mengakuisisi data-data analog maupun sinyalsinyal indikasi.

2. Melakukan control buka/tutup kontak, naik/turun setting atau fungsi-fungsi set point lainnya. 
3. Meneruskan hasil-hasil pengukuran (daya aktif, daya reaktif, frekuensi, arus, tegangan) dan sebagainya ke pusat pengendalian.

4. Melakukan komunikasi dengan pusat pengendalian.

Karena merupakan komponen yang sangat penting dalam sistem pengendalian, maka $R T U$ ini harus memiliki tingkat keandalan dan ketepatan (akurasi) yang tinggi, yang tidak boleh terpengaruh oleh gangguan-gangguan, misalnya noise, guncangan tegangan catu, dan sebagainya.

Fungsi-fungsi remote terminal unit antara lain:

a. Sebagai perangkat pemproses sinyal, $R T U$ dirancang untuk melakukan proses-proses sebagai perangkat pemproses pengiriman data ke pusat pengendalian sistem seperti:

- Perubahan status peraltan gardu

- Perubahan besaran-besaran analog

- Perubahan besaran signal

- Pembacaan harga-harga pulsa akumulator

- Pembacaan besaran-besaran analog

b. Memproses data-data perintah yang datang dari satu, dua atau tiga control center, mengirim data-data jawaban / hasil pengukuran / pemantauan ke pusat pengendali yang sesuai dengan yang telah ditetapkan.

Berdasarkan konfigurasinya maka suatu $R T U$ pada dasarnya dapat menangani atau memproses fungsi-fungsi sebagai berikut:

a. Akuisisi data logic (pensinyalan jarak jauh)

b. Akuisisi data analog (pengukuran jarak jauh)

c. Restitusi data logic (pengendalian jarak jauh)

d. Akuisis sinyal jarak jauh

e. Pengaturan set point, tap charger (untuk setting transformator), pengaturan perputaran generator dan sebagainya.

RTU S900 digunakan di GI-GI dengan I/O yang lebih banyak. RTU S900 ini mempunyai beberapa kelebihan antara lain :

- RTU S900 selain bisa dipakai sebagai RTU simple atau satelit juga bisa di pakai sebagai RTU Concentrator.

- Kapasitas dan kemampuan RTU S900 lebih besar

- Mempunyai beberapa protocol sehingga memungkinkan apabila akan terjadi penggantian Master Station

- Bisa lebih menghemat line data apabila RTU S900 di jadikan RTU Concentrator

RTU S900 tersusun dari card-card yang memiliki fungsinya masing-masing. Card-card yang menyusun RTU terdiri dari :

- CPU 900 ( Processing Unit )

- SAU 900 ( Serial Asynchronous Unit )

- DAU 900 ( Digital Acquisition Unit )

- DOU 900 ( Digital Output Unit )

- ACU 900 ( Analog to Digital Converter Unit )

- AAU 900 ( Analog Acquisition Unit )

- PCU 900 ( Power Converter Unit )
- Rack 900 (VME rack with Connected via Rear Panel connector)

Modul ini berfungsi sebagai pusat pengolah data dan sekaligus sebagai penyimpan Program dan Data, modul ini dilengkapi dengan :

- EEPROM 256 Kbytes

- Lampu led indikasi 9 buah

- Mikroprosesor 68020

- Secondary RAM 2/4 Mbytes

- Dua connector CCITT V24 ( untuk loading data dan indikasi apabila loading sukses )

- Rangkaian Timer

- Rangkaian Calendar

- 1 buah battery memory Lithium

- Rangkaian Watch Dog

- VME interface

Modul ini juga sebagai pusat down loading program maupun data dengan bantuan komputer atau laptop dan memakai program Procomm Plus

Modul ini berfungsi sebagai diffuser (interface) antara RTU S900 ke Modem MD 50 untuk komunikasi dengan Control Center, modul ini dilengkapi dengan :

- 1 led untuk indikasi

- 4 buah conector CCITT V24 ( untuk komunikasi dengan kecepatan 50 s/d 9600 Bauds )

- VME Interface

- 2 Komunikasi Kontrol (ACIA)

Modul ini berfungsi sebagai telesignal dan setiap modul mempunyai kapasitas 48 terminal masukan dan tiap-tiap masukan bertegangan +48 Vdc. Modul ini dalam pemakaiannya di mulai dari address $0,1,2$ dan seterusnya.

Untuk pemasangan modul ini bisa dibedakan menjadi dua yaitu untuk :

- Telesignal single/double

- Telesignal TAP Changer (graycode)

Untuk satu buah modul DAU 900 tidak boleh di campur dengan sinyal double dan single.Jadi setiap satu Modul harus di pakai untuk sinyal single saja atau sinyal double saja. Setiap masukan TS ini tidak dapat dihubungkan langsung ke peralatan Gardu Induk, karena Modul ini memakai tegangan $48 \mathrm{Vdc}$, sehingga untuk penyambungan ke peralatan Gardu Induk harus dipasang relay bantu.

Modul DAU 900 dilengkapi dengan :

- 1 led indikasi

- 48 opto coupler yang mempunyai tahanan isolasi $2,8 \mathrm{kV}$

- Interface circuit 24,48 dan $125 \mathrm{Vdc}$

- VME Interface

- DIN Connector to Plant

\section{Modul DOU 900 ( Digital Output Unit )}

Modul ini berfungsi memberikan / melanjutkan perintah open/close suatu peralatan Gardu Induk. Perintah open / close peralatan GI dapat juga diperoleh dari Control Center maupun secara lokal dari RTU S900. Modul ini memiliki alamat I/O 
sebanyak 32 dan dalam pemasangan di mulai dari Address 0, 1, 2 dan seterusnya. Modul ini dilengkapi dengan :

- 1 led indikasi

- 32 relay dengan tahanan isolasi sampai $2,8 \mathrm{kV}$ dan kekuatan kontak 2A-250 Vrms

- 1 Watch Dog

- VME Interface

- DIN Connector to plant

Modul ACU 900 ( Analog to Digital Converter Unit )

Modul ini berfungsi sebagai pengubah Informasi Analog yang datang dari modul Analog Acquisition Unit ( AAU 900 ) menjadi Informasi Digital, kemudian diproses oleh CPU lalu dikirim ke Control Center.

Karakteristik Modul ACU 900 :

- Mempunyai 3 macam fungsi kerja yaitu :

1. Menentukan skala Pengukuran

2. Mengkonversi skala pengukuran

3. Mengoreksi hasil konversi

- Mempunyai ketelitian skala 0,1\%

- Modul ini memakai power tegangan $+5 \mathrm{Vdc}-$ $26 \mathrm{~mA}$ dan $+12 \mathrm{Vdc}-30 \mathrm{~mA}$

\section{Modul AAU 900 ( Analog Acquisition Unit)}

Modul ini berfungsi untuk Telemetering (TM) , dan setiap modul mempunyai kapasitas 24 masukan pengukuran yang berbentuk arus searah maupun tegangan yang didapat dari Transducer untuk di konversi melalui Modul ACU 900. Hal ini dikerjakan setelah ada permintaan dari komputer Control Center. Pengukuran yang diterima dari Transducer ini disimpan pada condensator, discharge dari condensator menjadi input salah satu dari 24 Opto Coupler yang tersedia di modul itu kemudian di teruskan ke Modul ACU 900.

Modul ini mempunyai batasan input range sebagai berikut:

$\pm 5 \mathrm{~mA}, \pm 10 \mathrm{~mA}, \pm 20 \mathrm{~mA},+4 \sim+20 \mathrm{~mA}$

$\pm 1,25 \mathrm{~V}, \pm 2,5 \mathrm{~V}$ dan $\pm 5 \mathrm{~V}$

Modul AAU 900 dalam pemasangannya di mulai dari Address 0,1,2 dst. Cara penyettingan untuk address bisa di lakukan di Modul tersebut.

\section{Modul PCU 900 ( Power Converter Unit )}

Modul ini berfungsi sebagai distribusi tegangan untuk pemakaian seluruh modul pada RTU S900. Karakteristik modul ini sebagai berikut:

- Tegangan input $48 \mathrm{Vdc}$

- Range tegangan $42 \mathrm{Vdc}$ sampai dengan $52 \mathrm{Vdc}$ ($15 \% \mathrm{~s} / \mathrm{d}+20 \%)$

- Power output (+5V/12A \& +12V/1,5A)

Rangkaian proses terdiri dari instalasi/wiring, terminal, relay bantu dan transducer yang berfungsi untuk mengirim indikasi, kontrol, alarm-alarm dan pengukuran dari suatu Gardu induk/Pembangkit. Secanggih apapun sistem SCADA yang dipasang tidak akan ada artinya jika terjadi salah penyambungan/merangkai proses ke sistem Gardu Induk/Pembangkit. Untuk itu diperlukan pemahaman dalam memasang rangkaian proses ini. Secara umum rangkaian proses terdiri dari:

\section{Control Panel}

Pada lemari control panel inilah instalasi dan terminasi sistem SCADA paling banyak dipasang, karena pada dasarnya sistem SCADA itu memindahkan fungsi control panel ke control center (pusat pengaturan) secara real time. Indikasi, remote control dan telemetering dipasang pada lemari ini.

\section{Relay Panel}

Pada lemari relay ini dipasang peralatanperalatan proteksi, memasang instalasi dan terminasi untuk signal-signal alarm.

\section{Transducer Board}

Transducer merupakan suatu konverter yang berfungsi sebagai pengubah bentuk besaran energi yang satu ke besaran energi lain. Dalam telemetering untuk sistem SCADA, transducer digunakan untuk mengubah besaran listrik dari CT dan PT menjadi besaran miliampere.Fisik transducer ini cukup besar maka untuk memudahkan instalasi dan pemeliharaan maka ditempatkan pada satu lemari yaitu transducer board.

Komponen transducer yang dipakai di APD Makassar berasal dari vendor ENERDIS dengan produknya yang bernama TRIAD. TRIAD yang digunakan, mempunyai 2 tipe, yaitu: T32 (3 input, 2 output pengukuran) dan T33 (3 input, 3 output pengukuran). Masing - masing transducer disupply dengan tegangan $48 \mathrm{Vdc}$

\section{Supervisory Interface Cubicle (SIC)}

SIC ini merupakan terminal yang berfungsi sebagai pintu (gate) signal keluar dan masuk antara rangkaian proses dengan remote terminal unit (RTU). Pada SIC ini dilakukan pengelompokan sinyal-sinyal, penamaan bay-bay yang terdapat di suatu gardu induk/pembangkit. Ke sisi luar dihubungkan dengan rangkaian terminasi relay bantu dan transducer. Ke sisi dalam dilakukan pengalamatan/addressing ke card-card digital input (DI), analog input (AI), digital output (DO) dan analog output (AO).

SIC ini pada umumnya menggunakan disconnected terminal (terminal dimana kedua sisinya dapat dipisahkan) sehingga memudahkan dalam pemeliharaan.

Misalnya :

- memeriksa abnormalitas telesignalling, remote control dan telemetering.

- melakukan simulasi telesignalling, remote control dan telemetering.

\section{METODE PENELITIAN}

Telemetering adalah pengukuran besaranbesaran daya $\mathrm{MW} / \mathrm{MX} / \mathrm{A} / \mathrm{KV} / \mathrm{HZ}$ yang dibutuhkan sistem SCADA untuk dikirim ke control center sebagai bahan pengaturan sistem tenaga listrik. Untuk mengubah besaran-besaran daya yang bertegangan tinggi (CT/PT sekunder) menjadi output berarus lemah maka digunakan transducer. 
Dalam prosedur peluang maksimum, peluang yang akan diperoleh dari hasil pengukuran tergantung dari besarnya kesalahan acak yang terdapat pada perangkat pengukuran sebagaimana untuk menentukan parameter - parameter yang belum diketahui. Akan terlihat bahwa estimator peluang maksimum ternyata memerlukan probability density function(PDF) error acak pengukuran. Metode estimasi lain juga dapat digunakan dengan estimator least square yang tidak memerlukan PDF error pengukuran. Namun bila dianggap bahwa probability density function error pengukuran mengikuti distribusi normal, maka sebenarnya kedua cara tersebut akan memberikan formula estimasi yang sama. Hasilnya akan merupakan least square atau lebih dikenal dengan metode estimasi dengan weighted least square meskipun dikembangkan dengan menggunakan kriteria peluang paling besar.

Misalnya $\mathrm{z}^{\mathrm{ukur}}$ adalah nilai besaran pengukuran yang diterima dari perangkat pengukuran dan $\mathrm{z}^{\text {benar }}$ adalah harga sebenarnya dari besaran yang diukur. Dengan menganggap $\eta$ adalah kesalahan pengukuran, maka:

$$
z^{u k u r}=z^{\text {benar }}+\eta \text {. }
$$

Besar kesalahan acak $\eta$ merupakan model ketidak pastian untuk pengukuran di atas. Bila kesalahan pengukuran tidak menyimpang, maka probability density function dapat dinyatakan dengan:

$$
\operatorname{PDF}(\eta)=\frac{1}{\sigma^{2} \sqrt{2 \pi}} \exp \left(-\frac{\eta^{2}}{2 \sigma^{2}}\right)
$$

$\delta$ adalah standar deviasi dan $\delta^{2}$ disebut variance dari jumlah acak.

$\operatorname{PDF}(\eta)$ menggambarkan perilaku $\eta$

Standar deviasi $\delta$ dapat digunakan sebagai dasar untuk membuat model kesalahan acak pengukuran - pengukuran.Bila besar $\delta$ besar, pengukuran relative kurang teliti, sebaliknya bila harga $\delta$ kecil, terlihat adanya pancaran kesalahan kecil dari perangkat pengukuran, dengan demikian dapat kita lihat tidak ada suatu sistem pengukuran yang sempurna.Distrbusi normal umumnya digunakan sebagai model kesalahan pengukuran karena distribusi ini member hasil terhadap banyak faktor yang terkontribusi terhadap semua kesalahan.
Konsep estimasi dengan metode peluang maksimum digambarkan dengan menggunakan rangkaian sederhana seperti gambar 6.Besar sumber tegangan $x^{\text {benar }}$ ingin dicari dengan menggunakan amperemeter yang mempunyai kesalahan standar deviasi yang diketahui. Pembacaan meter adalah $z_{1}$ ukur yang besarnya sama dengan $z_{1}^{\text {benar }}$ yaitu besar arus sebenarnya yang mengalir pada rangkaian tersebut, dan 1 error yang terdapat pada meter tersebut.

$z_{1}^{\text {ukur }}=z_{1}^{\text {benar }}+\eta_{1} \ldots \ldots \ldots \ldots \ldots \ldots \ldots \ldots \ldots \ldots$ (3) Karena harga rata - rata $\eta_{1}$ sama dengan nol, maka $z_{1}{ }^{\text {ukur }}$ akan sama dengan $z_{1}^{\text {benar }}$. Dengan demikian probability density function untuk $z_{1}{ }^{\text {ukur }}$ adalah:

$\operatorname{PDF}\left(z_{1}^{u k u r}\right)=\frac{1}{\sigma^{2} \sqrt{2 \pi}} \exp \left(\frac{-\left(z_{1}^{u k u r}-z_{1}^{\text {benar }}\right.}{2 \sigma_{1}^{2}}\right)^{2}$

a. Formula Matriks

Bila fungsi $f_{i}\left(x_{1}, x_{2}, \ldots x_{N s}\right)$ merupakan fungsi linier maka persamaan (17) di atas akan mempunyai solusi yang dapat didekati dengan cara sebagai berikut, misalnya $f_{i}\left(x_{1}, x_{2}, \ldots x_{N S}\right)$ ditulis dalam bentuk sebagai berikut:

$f_{i}\left(x_{1}, x_{2}, \ldots x_{3}\right)=f_{i}(x)=h_{i 1} x_{1}+h_{i 2} x_{2}+\cdots+$

$H_{i N s} x_{s} \ldots \ldots \ldots \ldots . . .(27)$

Dalam bentuk vector dapa dituliskan :

$f(x)=\left[\begin{array}{c}f_{1}(x) \\ f_{2}(x) \\ \cdots \\ f_{N m}(x)\end{array}\right]=[H]_{x}$

Dimana :

$[H]=$ Matriks $N_{m} \times N_{s}$ yang mengandung koefisien fungsi fungsi linier $f_{i}(x)$

$N_{m}=$ Jumlah titik pengukuran

$N_{s}=$ Jumlah parameter yang akan ditentukan

\section{HASIL PEMBAHASAN}

\section{Data Penelitian yang Diperoleh}

Data-data yang diperoleh dari Area Penyaluran dan Pengatur Beban (AP2B) sistem Sulawesi Selatan berupa data bus, data line dan hasil pengukuran dengan menggunakan Remote Terminal Unit (RTU), yang terdiri dari data beban, Daya Aktif (MW) dan daya reaktif (MVAR). Penelitian ini membutuhkan data aliran daya tanggal 13 Februari 2011 sebagai data yang akan dijadikan bahan acuan penelitian sistem monitoring.

\begin{tabular}{|c|c|c|c|c|c|c|c|}
\hline \multirow{2}{*}{$\begin{array}{l}\text { No. } \\
\text { Sal. }\end{array}$} & \multicolumn{2}{|c|}{ Saluran } & \multicolumn{2}{|c|}{ Nama Saluran } & \multirow{2}{*}{$\underset{(\mathbf{p u})}{\mathbf{R}}$} & \multirow{2}{*}{$\underset{(\mathbf{p u})}{\mathbf{X}}$} & \multirow{2}{*}{$\begin{array}{l}1 / 2 \text { B } \\
\text { (pu) }\end{array}$} \\
\hline & dari & ke & dari & $\mathbf{K e}$ & & & \\
\hline 1 & 1 & 2 & Bakaru & Polmas & 0.02627 & 0.09440 & 0.00743 \\
\hline 2 & 1 & 4 & Bakaru & Pinrang & 0.03076 & 0.11023 & 0.01012 \\
\hline 3 & 2 & 3 & Polmas & Majene & 0.02630 & 0.09451 & 0.00744 \\
\hline 4 & 2 & 5 & Polmas & Parepare & 0.03663 & 0.13159 & 0.01819 \\
\hline 5 & 4 & 5 & Pinrang & Parepare & 0.01388 & 0.04974 & 0.00670 \\
\hline 6 & 5 & 7 & Parepare & Barru & 0.02314 & 0.08290 & 0.01116 \\
\hline 7 & 5 & 8 & Parepare & Pangkep & 0.04732 & 0.16958 & 0.02283 \\
\hline 8 & 6 & 5 & Suppa & Parepare & 0.00393 & 0.01413 & 0.00111 \\
\hline 9 & 7 & 8 & Barru & Pangkep & 0.02419 & 0.08667 & 0.01167 \\
\hline 10 & 8 & 9 & Pangkep & Bosowa & 0.01090 & 0.03919 & 0.00493 \\
\hline
\end{tabular}

Tabel 4.3 Data Impedansi Saluran 


\begin{tabular}{|c|c|c|c|c|c|c|c|}
\hline 11 & 8 & 10 & Pangkep & Tello & 0.02382 & 0.08535 & 0.01149 \\
\hline 12 & 8 & 25 & Pangkep & Pangkep70 & 0.00000 & 0.13164 & 0.00000 \\
\hline 13 & 9 & 10 & Bosowa & Tello & 0.01683 & 0.06049 & 0.00761 \\
\hline 14 & 10 & 11 & Tello & Tello lama & 0.00363 & 0.01300 & 0.00175 \\
\hline 15 & 10 & 12 & Tello & Panakukang & 0.00236 & 0.00848 & 0.00067 \\
\hline 16 & 10 & 13 & Tello & S.minasa & 0.00192 & 0.01318 & 0.00249 \\
\hline 17 & 10 & 30 & Tello & Tello 70 & 0.00000 & 0.20794 & 0.00000 \\
\hline 18 & 10 & 34 & Tello & Tello 30A & 0.00000 & 0.55350 & 0.00000 \\
\hline 19 & 11 & 32 & Tello lama & T. Lama 70 & 0.00000 & 0.41587 & 0.00000 \\
\hline 20 & 13 & 14 & S.minasa & Tj. Bunga & 0.00354 & 0.02128 & 0.00271 \\
\hline 21 & 15 & 13 & Tallasa & S.minasa & 0.00485 & 0.03324 & 0.00627 \\
\hline 22 & 16 & 17 & Sidrap & Makale & 0.03137 & 0.18876 & 0.02406 \\
\hline 23 & 16 & 5 & Sidrap & Parepare & 0.01002 & 0.03599 & 0.00283 \\
\hline 24 & 17 & 18 & Makale & Palopo & 0.01959 & 0.07039 & 0.00554 \\
\hline 25 & 19 & 16 & Soppeng & Sidrap & 0.02821 & 0.10138 & 0.00964 \\
\hline 26 & 19 & 21 & Soppeng & Bone & 0.02289 & 0.08153 & 0.00804 \\
\hline 27 & 20 & 19 & Sengkang & Soppeng & 0.01053 & 0.06335 & 0.00807 \\
\hline 28 & 21 & 23 & Bone & Bulukumba & 0.07195 & 0.25851 & 0.02035 \\
\hline 29 & 21 & 22 & Bone & Sinjai & 0.04064 & 0.14603 & 0.01149 \\
\hline 30 & 22 & 23 & Sinjai & Bulukumba & 0.03131 & 0.11249 & 0.00885 \\
\hline 31 & 23 & 24 & Bulukumba & Jeneponto & 0.02431 & 0.08733 & 0.00687 \\
\hline 32 & 24 & 15 & Jeneponto & Tallasa & 0.03333 & 0.11974 & 0.00942 \\
\hline 33 & 25 & 26 & Pangkep70 & Tonasa 3 & 0.01638 & 0.03006 & 0.00009 \\
\hline 34 & 25 & 27 & Pangkep70 & Maros & 0.08188 & 0.15032 & 0.00045 \\
\hline 35 & 25 & 28 & Pangkep70 & Mandai & 0.18159 & 0.33335 & 0.00100 \\
\hline 36 & 27 & 28 & Maros & Mandai & 0.13631 & 0.25024 & 0.00075 \\
\hline 37 & 28 & 29 & Mandai & Daya & 0.03420 & 0.06278 & 0.00019 \\
\hline 38 & 30 & 28 & Tello 70 & Mandai & 0.05828 & 0.10699 & 0.00032 \\
\hline 39 & 30 & 29 & Tello 70 & Daya & 0.02408 & 0.04421 & 0.00013 \\
\hline 40 & 31 & 30 & Barangloe & Tello 70 & 0.06069 & 0.11141 & 0.00034 \\
\hline 41 & 32 & 33 & T. Lama 70 & Bontoala & 0.02023 & 0.03714 & 0.00011 \\
\hline 42 & 34 & 36 & Tello 30A & Barawaja & 0.12292 & 0.17508 & 0.00002 \\
\hline 43 & 35 & 30 & Tello 30B & Tello 70 & 0.00000 & 0.55350 & 0.00000 \\
\hline 44 & 3 & 37 & Majene & Mamuju & 0.01002 & 0.01002 & 0.00283 \\
\hline
\end{tabular}

Sumber: AP2B PT. PLN (Persero) Wilayah SULSELTRABAR

suatu saluran transmisi akan mempunyai resistansi dan induksi seri, yang bersama-sama membentuk impedansi seri dari kawat-kawat penghantar, serta konduktansi dan kapasitansi shunt dari dielektrikum yang terdapat di antara penghantar-penghantar, yang bersama-sama membentuk admitansi shunt dari saluran.

Nilai konstanta-konstanta primer pada tabel 4.3 konstan dalam arti tidak berubah dengan tegangan dan arus, tetapi sampai batasbatas tertentu dipengaruhi oleh frekuensi.

a. Pengukuran Dengan Menggunakan Remote Terminal Unit

Tabel 4.4 berikut merupakan hasil pengukuran daya aktif (MW) dan daya reaktif (MVAR) saluran dengan menggunakan RTU.

Tabel 4.4 hasil pengukuran daya aktif dan daya reaktif saluran dengan Remote Terminal Unit (RTU)

\begin{tabular}{|c|r|l|c|c|c|c|c|}
\hline dari & ke & nama bus saluran & mva limit & $\begin{array}{c}\text { hasil } \\
\text { pengukuran } \\
(\mathbf{m w})\end{array}$ & ampere & mvar & kha \\
\hline 1 & 2 & bakaru- polmas & 90 & 43.885 & 214 & -7.425 & 600 \\
\hline 1 & 4 & bakaru - pinrang & 90 & 0.891 & 243 & 0.891 & 600 \\
\hline 2 & 3 & polmas- majene & 180 & 6.204 & 53 & -5.94 & 600 \\
\hline 2 & 5 & polmas - parepare & 90 & 51.28 & 117 & -4.95 & 600 \\
\hline 4 & 5 & pinrang - parepare & 90 & 50.422 & 178 & -8.184 & 600 \\
\hline 5 & 7 & parepare - barru & 90 & 52.171 & 310 & 5.247 & 600 \\
\hline 6 & 5 & suppa - parepare & 180 & 24.848 & 124 & 7.623 & 600 \\
\hline
\end{tabular}




\begin{tabular}{|c|r|l|c|c|c|c|c|}
7 & 8 & barru - pangkep & 90 & 64.248 & 294 & 154.136 & 600 \\
\hline 8 & 9 & pangkep - bosowa & 90 & 42.667 & 241 & 2.673 & 600 \\
\hline 8 & 10 & pangkep - tello & 180 & 62.466 & 227 & -5.445 & 600 \\
\hline 9 & 10 & bosowa - tello & 90 & 25.244 & 164 & -3.465 & 600 \\
\hline 10 & 11 & tello - tallo lama & 180 & 23.957 & 130 & 0.198 & 600 \\
\hline 10 & 12 & tello - panakukang & 180 & 21.973 & 95 & 6.47 & 600 \\
\hline 10 & 13 & tello - s.minasa & 180 & 3.135 & 50 & 7.775 & 800 \\
\hline 13 & 14 & s.minasa - tj. bunga & 480 & -18.603 & 85 & -7.626 & 800 \\
\hline 16 & 17 & sidrap - makale & 180 & 20.195 & 78 & -0.66 & 800 \\
\hline 16 & 5 & sidrap - parepare & 180 & 5.148 & 56 & -5.148 & 600 \\
\hline 19 & 16 & soppeng - sidrap & 180 & 43.12 & 165 & 4.7 & 600 \\
\hline 19 & 21 & soppeng - bone & 180 & 56.53 & 218 & 8.9 & 600 \\
\hline 20 & 19 & sengkang - soppeng & 240 & 33.004 & 390 & -4.807 & 800 \\
\hline 21 & 23 & bone - bulukumba & 90 & 18.667 & 170 & -1.65 & 600 \\
\hline 21 & 22 & bone - sinjai & 90 & 21.053 & 191 & 0.726 & 600 \\
\hline 23 & 24 & bulukumba - jeneponto & 180 & 0 & 143 & 0 & 600 \\
\hline 25 & 26 & pangkep70 - tonasa 3 & 56 & 7.316 & 63 & 5.495 & 400 \\
\hline 25 & 27 & pangkep70 - maros & 28 & 14.845 & 278 & 4.888 & 400 \\
\hline 25 & 28 & pangkep70 - mandai & 56 & 10.193 & 26 & 3.281 & 400 \\
\hline 27 & 28 & maros - mandai & 28 & 6.998 & 29 & 2.12 & 400 \\
\hline 28 & 29 & mandai - daya & 28 & 0.273 & 138 & 0.395 & 400 \\
\hline 30 & 28 & tello 70 - mandai & 28 & 13.47 & 112 & -0.54 & 400 \\
\hline 30 & 29 & tello 70 - daya & 28 & 0.273 & 315 & 0.334 & 400 \\
\hline 31 & 30 & barangloe - tello 70 & 28 & -0.023 & 93 & 0.159 & 400 \\
\hline 32 & 33 & t. lama 70 - bontoala & 56 & 47.041 & 171 & -93.216 & 400 \\
\hline
\end{tabular}

Sumber: AP2B PT. PLN (Persero) Wilayah SULSELTRABAR

Data pada tabel diambil berdasarkan hasil pengukuran Remote Terminal Unit (RTU) pada setiap saluran yang terdapat pada GI.
Saluran yang dapat dimonitoring dengan menggunakan RTU adalah sebanyak 29 saluran dari 44 saluran yang ada dalam sistem.

Tabel 4.5 Hasil pengukuran Aliran daya dengan menggunakan RTU

\begin{tabular}{|c|c|c|c|c|c|c|c|}
\hline \multirow[b]{2}{*}{ Nama Bus } & \multirow[b]{2}{*}{ Tipe Bus } & \multirow[b]{2}{*}{$\begin{array}{c}\text { Teganga } \\
n \\
(\mathrm{KV})\end{array}$} & \multicolumn{2}{|c|}{ Beban } & \multicolumn{2}{|c|}{ Pembangkitan } & \multirow[b]{2}{*}{$\begin{array}{c}\text { Injekasi Q } \\
\text { (MVAR) }\end{array}$} \\
\hline & & & $\begin{array}{c}\mathrm{P} \\
(\mathrm{MW})\end{array}$ & Q (mvar) & $\begin{array}{c}\mathrm{P} \\
(\mathrm{MW})\end{array}$ & $\underset{(\mathrm{mvar})}{\mathrm{Q}}$ & \\
\hline Bakaru & Slack Bus & 152.3 & 5.136 & 1.437 & 62.1 & -4.8 & 0 \\
\hline Polmas & Beban & 154.99 & 5.328 & 1.861 & 0 & 0 & 0 \\
\hline Majene & $\begin{array}{c}\text { Pembangki } \\
\mathrm{t}\end{array}$ & 155.6 & 4.765 & 1.439 & 0 & 0 & 0 \\
\hline Pinrang & $\begin{array}{c}\text { Pembangki } \\
t\end{array}$ & 149.989 & 5.552 & 1.936 & 0.6 & 0 & 0 \\
\hline Parepare & Beban & 148.896 & -4.497 & -0.079 & 0 & 0 & 0 \\
\hline Suppa & $\begin{array}{c}\text { Pembangki } \\
t\end{array}$ & 148.896 & 15.32 & 0 & 51.8 & 16.5 & 0 \\
\hline Barru & Beban & 147.99 & 1.243 & 0.692 & 0 & 0 & 0 \\
\hline $\begin{array}{l}\text { Pangkep } \\
\end{array}$ & Beban & 144.78 & 15.787 & 5.385 & 0 & 0 & 0 \\
\hline Bosowa & Beban & 147.2 & 18.76 & 0 & 0 & 0 & 0 \\
\hline Tello & $\begin{array}{c}\text { Pembangki } \\
\mathrm{t}\end{array}$ & 145 & 44.12 & 18.2 & 138 & 81.2 & 0 \\
\hline
\end{tabular}




\begin{tabular}{|l|c|c|c|c|c|c|c|} 
Tello lama & Beban & 147.89 & 24 & 19.271 & 0 & 0 & 0 \\
\hline $\begin{array}{l}\text { Panakukan } \\
\text { g }\end{array}$ & Beban & 142.67 & 42.751 & 6.49 & 0 & 0 & 0 \\
\hline S.Minasa & Beban & 148.33 & 11.021 & 2.639 & 0 & 0 & 0 \\
\hline Tjg. Bunga & Beban & 145.89 & 15.161 & -0.044 & 0 & 0 & 0 \\
\hline Soppeng & Beban & 154.893 & 3.371 & 6.727 & 0 & 0 & 0 \\
\hline Sengkang & $\begin{array}{c}\text { Pembangki } \\
\mathrm{t}\end{array}$ & 151.45 & 14.773 & 5.296 & 219 & 71.23 & 0 \\
\hline Bone & Beban & 148.513 & 18.637 & 5.86 & 0 & 0 & 0 \\
\hline Maros & Beban & 68.073 & -0.025 & 0.016 & 0 & 0 & 0 \\
\hline Mandai & Beban & 69.292 & 32.866 & 25.91 & 0 & 0 & 0 \\
\hline Daya & $\begin{array}{c}\text { Pembangki } \\
\mathrm{t}\end{array}$ & 69.616 & -22.667 & -1.32 & 0 & 0 & 0 \\
\hline Barangloe & Beban & 69.574 & 0.158 & -6.142 & 0 & 0 & 0 \\
\hline Bontoala & $\begin{array}{c}\text { Pembangki } \\
\mathrm{t}\end{array}$ & 69.602 & 41.23 & 15.57 & 13 & 9.334 & 0 \\
\hline
\end{tabular}

Aliran daya mencakup perhitungan aliran dan tegangan sistem pada terminal tertentu atau bus tertentu. Representasi fasa tunggal selalu dilakukan karena sistem dianggap seimbang. Didalam studi aliran daya bus-bus dibagi dalam 3 macam, yaitu :

1. Slack Bus atau swing bus merupakan bus referensi

2. Voltage controlled bus atau bus generator/Pembangkit

3. Load bus atau bus beban

Pada tiap-tiap bus terdapat 4 besaran, yaitu :

1. Daya riil atau daya nyata $P(\mathrm{MW})$

2. Daya reaktif $\mathrm{Q}$ (MVAR)

3. Harga skalar tegangan

Data-data inilah yang akan digunakan sebagai bahan informasi untuk mengesitimasi nilai tegangan dan sudut fasa dengan menggunakan WLS.

Hal ini merupakan satu indikasi terjadinya bad measurement pada bus 27 dan 29. Bad measurement bisa terjadi pada sistem karena kesalahan informasi yang masuk ke master station yang disebabkan oleh kesalahan pada alat ukur yang

tidak dikalibrasi atau terputusnya system komunikasi ke master station.

Bad Measurement yang terjadi pada bus akan menyebabkan tingkat keamanan system Kelistrikan berkurang. Sistem monitoring yang kurang handal akan mempengaruhi analisa kontingensi dan tidakan kurektif yang diterapkan pada suatu system kelistrikan.

Selain kelebihan yang dimiliki oleh Remote Terminal Unit (RTU), seperti yang dibahas pada BAB II, berdasarkan hasil penelitian ada beberapa kekurangan yang dimiliki oleh sistem monitoring PT. PLN (Persero) dengan menggunakan RTU, antara lain:

a. Sistem Wiring yang sangat rumit

Pengembangan remote station dengan cara konvensional menggunakan Remote Terminal Unit (RTU) membutuhkan SDM yang memadai dan waktu pengerjaan yang lama karena harus dilakukan wiring point to point. b. Adanya beberapa Gardu Induk yang tidak terhubung dengan master station dan beberapa yang lain tidak memiliki remote station sehingga hasil pengukuran di GI tersebut tidak dapat dikomunikasikan ke control center melalui sistem SCADA.

c. RTU di GI Bulukumba dan GI Takalar dalam kondisi tidak baik.

Berdasarkan kekurangan di atas, PT. PLN (Persero) Wilayah SULSELTRABAR sedang melakukan pengembangan sistem monitoring berbasis software yang dikenal dengan nama SCADA Gateway.

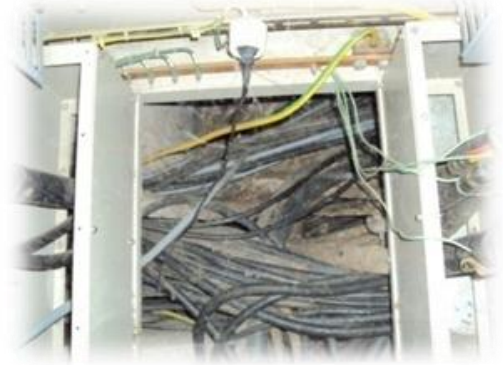

Gambar 1. Wiring System dengan menggunakan sistem konvensional

Pengembangan sistem SCADA Gateway memberikan keuntungan diantaranya :

- Terdapat backup data di masing-masing GI, sehingga jika putus komunikasi atau gangguan di Control Center, data-data masih dapat diperoleh di masing-masing GI.

- Operator Lokal di GI dapat mengoperasikan GI terkait melalui lokal HMI.

- Dengan SCADA Gateway, yang memiliki sumber yang sama dengan yang terkirim ke Control Center, kesalahan data yang terkirim ke Pusat Kontrol dapat diminimalkan, karena operator GI dapat membandingkan data di komputer lokal dengan data yang di control panel setiap saat bila dideteksi ada kesalahan data. 
- GI yang belum terhubung ke Control Center tetap dapat dioperasikan melalui komputer lokal, sehingga data historikal GI sudah tersedia di komputer GI terkait.

- Sistem wiring sederhana, karena tidak dibutuhkan lagi wiring point to point dari control panel ke kubikel interface sisi RTU, tapi wiring langsung dilakukan di panel kontrol ke IED atau Distributed I/O, lalu output dihubung ke SCADA Gateway.

- Metering dengan IED meter lebih efektif dan dipantau dari lokal/pusat kontrol.

\section{KESIMPULAN}

Berdasarkan uraian dan pembahasan hasil penelitian, maka dapat diambil kesimpulan yaitu Bad measurement yang terjadi pada bus akan menyebabkan berkurangnya tingkat keandalan sistem. Kesalahan ukur atau bad measurement dapat disebabkan oleh putusnya komunikasi dari GI ke control center atau tidak terkalibrasinya alat ukur yang ada di gardu induk. Sehingga terjadi kesalahan informasi pada control center.

\section{DAFTAR PUSTAKA}

[1] Bonar Pandjaitan, 1999. Teknologi Sistem Pengendalian Tenaga Listrik Berbasis SCADA, Prenhallindo, Jakarta.

[2] Arief Basuki, Timbar Imam Priadi, Anita Puspita Sari, 2010. SCADA GATEWAY, Solusi Cerdas untuk PEngembangan Substation Automation: PT. PLN (Persero) Wilayah SULSEL, SULTRA, dan SULBAR, AP2B Sistem SULSEL, Makassar

[3] Wood, Allen J., B. F. Wollenberg, 1996. Power Generation, Operation, and Control. New York: John Wiley \& Sons, Inc

[4] Ali Abur, Antonio Gomez Exposito, Power System State Estimation: Theory and Implementation (Power Engineering, 24), Marcel Decker, New York,

[5] James R Schott, 1997. Matrix Analysis for Statistics, New York: John Wiley \& Sons, Inc

[6] Cobus Strauss, 2003. Practical Electrical Network Automation and Communication Systems, Newnes Elsevier; Oxford.

[7] Jim Iverson, 2007. Digital control technology enhances power system reliability and performance www.cumminspower.com. Diakses tanggal 28 Januari 2010

[8] J.B.A London Jr, George L. R de Brito and N.G Bretas, 2003. Method for Meter and RTU Placement for State Estimation Purposes. Proceedings of the IEEE Bologna Power Tech Conference: Bologna, Italia

[9] Marek Zima, Operation, monitoring and control Technology of Power System, www.eeh.ee.ethz.ch/uploads/tx_ethstudies.

Diakses tanggal 28 Januari 2010
[10] R. Neela, R. Ashokkumar, 2010. A Robust Decoupled WLAV State Estimation For Power Systems: International Journal of Engineering Science and Technology.

[11] Rakesh Babba, 2010. Detecting False Data Injection Attacks Against DC State Estimation: University of Illinois Urbania

[12] Reynaldo Fransisco Nuqui, 2001. State Estimation and Voltage Security Monitoring Using Synchronized Phasor Measurements: Blacksburg, Virginia.

[13] Stuart A Boyer, 2004. SCADA: Supervisory Control and Data Acquisition. Edisi 3, ISA-The Instrumentation, Systems and Automation Society ; University of Virginia

[14] Trosten Cegrell,1986. Power System Control Technology, Prentice/Hall Company.

[15] T. Kerdchuen, W. Ongsakul, 2006. Measurement and RTU Placement for State Estimation by Loop Decompotition: Issue and Prospects for GMS
Copyright@2016 PROtek : Jurnal Ilmiah Teknik Elektro (c) $($ ) $\$$ (isensi Creative Commons Attribution 4.0 cc) 